1. Беленов Л. Д. Валторна: Монография. М.: Российская академия музыки имени Гнесиных, 2004. 320 c.

2. Левин С. Я. Духовые инструменты в истории музыкальной культуры. Л.: Музыка, 1973. $262 \mathrm{c}$.

3. Полех Л.В. История создания и история интерпретации концертов для валторны В. А. Моцарта//Вопросы музыкальной педагогики. Bып. 10. М.: Музыка, 1991. C. 130-146.

4. Усов Ю. А. История отечественного исполнительства на духовых инструментах. М.: Музыка, 1975. $195 \mathrm{c}$.

5. Шоллар Ф. Школа игры на валторне. М., 1965. 140 с.

\title{
References
}

1. Belenov, L.D. (2004). French horn: Monograph [Valtorna: Monografiya]. Moscow, The Gnesins Russian Academy of Music. 320 p.

2. Levin, S. Ya. (1973). Wind Instruments in the History of Musical Culture [Duhovyie instrumentyi $v$ istorii muzyikalnoy kulturyi]. Leningrad, Music. 262 p.

3. Polekh, L.V. (1991). History of the creation and history of the interpretation of concerts for the French horn of V.A. Mozart. Questions of musical pedagogy [Istoriya sozdaniya $i$ istoriya interpretatsii kontsertov dlya valtornyi V. A. Motsarta. Voprosyi muzyikalnoy pedagogiki]. Issue. 10. Moscow, Music. P. 130-146.

4. Usov, Yu. A. (1975). History of domestic performance on wind instruments [Istoriya otechestvennogo ispolnitelstva na duhovyih instrumentah]. Moscow, Music. 195 p.

5. Shollar, F. (1965). School of the French horn [Shkola igryi na valtorne]. Moscow, 140 p.

УДК 78.071.1(438)

ORCID: 0000-0002-1457-8335

Вікторія Нечепуренко, кандидат мистецтвознавства, доцент кафедри історії музики Київського інституту музики ім. Р. М. Глієра, вул. Льва Толстого 31, Київ, 01032, Украӥна

Viktoria Nechepurenko, Ph.D. in Arts, Associate Professor at the Department of Music History, R. Glier Kyiv Institute of music, 31 Lva Tolstogo St., Kyiv 01032, Ukraine

\section{НОКТЮРН ор. 16 І. Я. ПАДЕРЕВСЬКОГО: СТИЛЬОВИЙ ТА ІНТЕРПРЕТАЦІЙНИЙ АСПЕКТИ}

Mema cmammi. Виявити стильові особливості Ноктюрну ор. 16 №4 I. Я. Падеревського, а також інтерпретаційну варіантність його тексту на прикладі виконавських версій К. Кіннера і Х. Рутковського. Проаналізувати індивідуальні риси композитора на прикладі даного твору. Методологія дослідження передбачає застосування теорії інтерпретації, розробленої В. Г. Москаленко, а також історичного та компаративного аналізу, які 
слугують підвалинами у даній розвідці. Наукова новизна дослідження полягає у тому, що вперше в українському музикознавстві проаналізовано Ноктюрн І.Я. Падеревського у стильовому та інтерпретаційному аспектах. Висновки. Обраний для аналізу твір І. Падеревського є яскравим зразком пізньоромантичної фортепіанної мініатюри. В ньому, 3 одного боку проявляється відданість створеній Ф. Шопеном традиції, а 3 іншого присутні тенденції музичної мови доби fin de siècle. Прикладом багатогранності музичного тексту Ноктюрну І. Падеревського стають дві виконавські версії створені Х. Рутковським і К. Кіннером.

Ключові слова: виконавські версії, інтерпретація, польські композитори, фортепіанна мініатюра, ноктюрн.

Nocturne op. 16 by I. J. Paderewski: stylistic and interpretative aspects. The aim of this article is twofold. First, to identify the stylistic features of the Nocturne Op. 16 No.4 by I. J. Paderewski and the interpretative variability of its score, based on the performing versions by K. Kenner and H. Rutkowski, and secondly, to analyze the composer's individual traits using this piece as an example.

The study methodology involves the use of the theory of interpretation developed by Viktor Moskalenko, as well as the historical and comparative analyses that form the basis for this research.

The scientific novelty of this study lies in the fact that for the first time in the Ukrainian musicology the Nocturne by I. J. Paderewski is analysed in stylistic and interpretative aspects.

Conclusions. The piece of I. J. Paderewski chosen for the analysis is a vivid example of the late Romantic piano miniature. In the nocturne, on the one hand, a dedication to the tradition established by F. Chopin becomes apparent, and on the other, the trends of the musical language of the fin-de-siècle epoch are present. The two performing versions created by $H$. Rutkowski and K. Kenner are examples of the interpretative variants of Paderewski's Nocturne.

Keywords: performing versions, interpretation, Polish composers, piano miniature, nocturne.

Ноктюрн ор. 16 И. Я. Падеревского: стилевой и интерпретационный аспекты. Цель статьи. Выявить стилевые особенности Ноктюрна ор. 16 №4 И. Я. Падеревского, а также интерпретационную вариантность его текста на примере исполнительских версий К. Киннера и Х. Рутковского. Проанализировать индивидуальные стилевые черты композитора на примере данного произведения. Методология исследования предполагает привлечение теории интерпретации разработанной В. Г. Москаленко, а также исторического и 
компаративного анализа, которые служат основой в данной статье. Научная новизна заключается в том, что впервые в украинском музыковедении анализируется Ноктюрн И. Я. Падеревского в стилевом и интерпретационном аспектах. Bыводы. Выбранное для анализа произведение И. Падеревского - яркий пример позднеромантической фортепианной миниатюры. В нем, с одной стороны проявляются преданность созданной Ф. Шопеном традиции, а с другой - присутствуют тенденции музыкального языка эпохи fin de siècle. Пример многогранности музыкального текста Ноктюрна И. Падеревского становятся две исполнительские версии, созданные Х. Рутковским и К. Киннером.

Ключевые слова: исполнительские версии, интерпретация, польские композиторы, фортепианная миниатюра, ноктюрн.

Актуальність теми. 3 нагоди сторічного ювілею незалежності Польщі, який святкують впродовж 2018 року по всьому світі, хочеться пригадати імена видатних постатей, які накопичували та зміцнювали духовну спадщину країни в різні історичні періоди. У ХІХ ст. найяскравішими i найвідомішими репрезентантами польської культури у світі були Фредерік Шопен, Станіслав Монюшко, Адам Міцкевич та ін.; у ХX ст. Польщу прославляли Кароль Шимановський, Станіслав Лем, Вітольд Лютославський, Кшиштоф Пендерецький; а польські кіно-шедеври Єжи Гоффмана та Анджея Вайди відомі майже кожному сучасному глядачу ${ }^{1}$ До вищеназваних митців слід також додати ім'я видатного піаніста, композитора і суспільного діяча Ітнація Яна Падеревського (1860-1941), кар'єра якого розгорталася в один 3 найскладніший для польської культури період - кінець ХІХ-п.п.ХХ ст.

Для Польщі межа століть стала вирішальною щодо подальшого розвитку усієї нації. 3 проголошеною у 1918 році незалежністю для «новонародженої» країни відкривається нова сторінка в історії. I в цьому контексті значення постаті I. Я.Падеревського, як для польської культури, такі історії держави загалом, складно переоцінити. Майже у кожному польському довіднику зазначається, що І. Я. Падеревський був найвідомішим поляком на зламі століть, першим польським піаністом, який мав честь виступити з сольним концертом в Карнегі Холл, та був єдиним польським композитором, оперу якого («Манру», 1901 р.) було поставлено в Метрополітен-опера [4; 9; 10]. Нарешті, дипломатичній діяльності І. Падеревського поляки завдячують за те, що після сторічної

\footnotetext{
${ }^{1}$ Безперечно, цей перелік імен є неповним і його можна продовжувати.
} 
відсутності Польщі на мапі Європи, вона відновила свій статус незалежної держави. Тому не дивно, що сьогодні навчальні заклади, різні мистецькі організації, музичні конкурси і фестивалі носять його ім'я.

Деталі творчості та діяльності I. Падеревського досліджені польськими науковцями: написано чимало статей, монографій і різної за жанром літератури $[4 ; 9 ; 10]$, а інтернет буквально «тріщить по швах» від інформації про музиканта ${ }^{1}$.

Натомість українські слухачі і музиканти знають І. Падеревського, в першу чергу, завдяки його редакторській інтерпретації творів Фредеріка Шопена ${ }^{2}$, тоді як композиторська творчість митця i його досягнення, як піаніста-віртуоза залишаються маловідомі. Однак сучасна соціокультурна ситуація сприяє тому, що на новому етапі українськопольських культурних зв'язків, такий знаний майстер як I. Я. Падеревський потребує нового осмислення. 3 цим пов'язано звернення до доробку І. Падеревського у нашій статті об'єктом якої обрано стильові особливості фортепіанної творчості композитора, а предметом - авторський задум Ноктюрна ор. 16 №4 i його інтерпретаційні версії К. Кіннера і Х. Рутковського. Методологічною базою слугувала теорія інтерпретації, яка розроблена В. Г. Москаленко, а також історичні та компаративні методи аналізу.

Mema статті - виявити стильові та інтерпретаційні особливості Ноктюрну ор.16 №4 І. Я. Падеревського на прикладі виконавських версій К. Кіннера і Х. Рутковського. В зв'язку із поставленою метою, виникла необхідність вирішення наступних завдань:

- $\quad$ розглянути культурний контекст, який передував створенню I. Я. Падеревським обраного для аналізу твору;

- проаналізувати текст Ноктюрну ор. 16 № 4 в композиторського задуму;

- п порівняти дві інтерпретаційні версії Ноктюрну створені К. Кіннером та Х. Рутковським.

Після закінчення варшавської консерваторії, 3 метою самовдосконалення у 1884 році Падеревський виїжджає до Відня, де навчається у відомого польського піаніста i викладача Теодора Лешетицького. Після роботи і спілкування 3 легендарним викладачем, який виховав чимало відомих виконавців (А. Шнабеля,

\footnotetext{
1 На запит польською мовою «Paderewski» пошукова система «Google» пропонує 1160000 позицій, що видається більш ніж переконливим результатом, як для академічного музиканта.

${ }^{2}$ Визначення В. Г. Москаленка [3].
} 
О. Брайловського, А. Ссипову, І. Венгерову), розпочались гастрольні турне I. Я. Падеревського і географія його виступів значно розширилася. За роки піаністичної кар'єри музиканта він не лише відвідав усі країни Європи, але й виступав на всіх континенти (I. Падеревський навіть доїхав до Австралії та Нової Зеландії).

Перший надзвичайний успіх у Європі очікував піаніста у французькій столиці. Безумовно, ореол Парижа кінця XIX століття, як культурної Мекки усього світу приваблював I. Падеревського можливістю одразу стати відомим. Але, ще однією причиною зацікавлення саме цим містом і країною у цілому могли бути польськофранцузькі культурні відносини, які мають тривалу історію. Як відомо 3 історії Польщі, протягом XIX століття країна пережила декілька хвиль еміграції поляків до Франції. Як зазначає у своїй дисертаційній роботі польська дослідниця Олександра Байєрська у 1890 році (третя хвиля еміграції) в Парижі налічувалося близько трьох тисяч поляків [6, s. 137]. Дослідниця також відзначає, що для поляків французька столиця стала важливим центром культурного життя, де польські митці намагалися наслідувати тенденції європейського мистецтва i реалізувати власні здібності [6, s. 44].

Починаючи 31888 року про І. Я. Падеревського довідується французька публіка і представники вищих кіл Франції. У пресі того періоду знаходимо декілька показових записів ${ }^{1}$. Так, наприклад, Мистецька газета Нанту у жовтні 1890 року інформує про прикрий випадок: «...піаніст Падеревський, перебуваючи на відпочинку в Амфіоні у своєї видатної покровительки принцеси Бранкован, став жертвою неприємного випадку, він зламав ногу. Наразі блискучий віртуоз повинен залишатися у спокої впродовж сорока днів і не може покинути віллу принцеси» [8]. Із цього короткого повідомлення довідуємося про коло спілкування Покровителькою композитора була відома наприкінці століття

\footnotetext{
1 Друге повідомлення у тій самій французькій газеті з'явилося у 1891 році. «Падеревський повернувся до нас втретє - пише нантське видання, - і як завжди був прийнятий з ентузіазмом. Видатний піаніст мав абсолютний тріумф після виконання свого чудового Концерту для фортепіано. Інтерпретацію Ноктюрна і Скерцо Шопена супроводжували нескінченні овації, так само як і фантазію на тему «Дон Жуана». Під час подвійного «бісу» Падеревський виконав свій чарівний Менует і Угорський танець Й. Брамса. Не варто додатково зазначати, що в цих двох творах він, як завжди, був неперевершений». I далі: «Успіх Падеревського можна дорівнювати справжньому тріумфу; його викликали оваціями після кожного твору» [8].
} 
французька поетеса і романістка, принцеса Анна Бранкован (після одруження - графиня Анна-Елізабет де Ноайє). На початку XX століття iii салон відвідували найвідоміші інтелектуали, літератори і артисти французької столиці. Серед знаних гостей були Поль Клодель, Андре Жид, Робер де Монтеск'є, Поль Валері, Альфонс Доде, а також Колетт і Жан Кокто. А в їі відомому будинку в Амфіоні, де перебував на відпочинку Падеревський гостював один 3 найвидатніших французьких письменників, Марсель Пруст (який, до речі, захоплювався творчістю молодої поетеси).

Принцеса Бранкован стала першою в історії жінкою, яка не лише отримала премію від Французької Академії, але й була прийнята до Бельгійської Королівської академії мови та літератури. Показово, що частиною цього вищого світу, еліти Франції був І. Я. Падеревський. Про теплі стосунки композитора із родиною принцеси свідчать також численні присвяти творів композитора, зокрема матері графині АннаЕлізабет де Ноайє, грецькій піаністці Ралуці Муссурос (відомій під ім'ям Рашель Мусурус).

Родина Рашель Мусурус зайняла особливе місце в життя музиканта, а сама піаністка стала однією 3 найвірніших муз I. Падеревського. Доводом цього може стати Ноктюрн B-dur op. 16 № 4 присвячений грецькій виконавиці.

Поряд із такими відомими творами I. Я. Падеревського для фортепіано, як Легенда As-dur, Мелодія Ges-dur та інші з 16 опусу, Ноктюрн B-dur № 4 входить до числа найвідоміших i найчастіше виконуваних мініатюр польського композитора.

Ноктюрн зацікавлює оригінальністю композиторського задуму. 3 одного боку, його можна вважати типово романтичним твором (жанрові ознаки, фактурне вирішення, загальний характер звучання), а з іншого він має індивідуальні риси, які виділяють «почерк» Падеревськогокомпозитора серед інших романтиків.

До характерних для романтичних фортепіанних мініатюр рис слід віднести структуру ноктюрну. Він написаний у тричастинній формі, де у кожному розділі композитор дотримується структурної чіткості. Так, перший розділ (12+12 тактів) - період, який складається 3 двох завершених речень; середній розділ (28 тактів) типу тріо, який має контрастний характер і витриманий у романтичних традиціях; показова для романтиків скорочена динамізована реприза (12 т.) і кода (10 т.).

Типовою можна вважати і назву твору, яка відсилає слухача до найкращих зразків жанру ноктюрну написаних Д. Фільдом і Ф. Шопеном. 
Однак, незважаючи на заголовок, тематизм мініатюри I. Падеревського виходить за межі обраного жанру, видається більш об'ємним і багатшим за своїм семантичним наповненням. I в цьому, на наш погляд, виявляються індивідуальні риси стилістики польського композитора i його авторський задум у даному творі.

Аналізуючи тематизм першого розділу помічаємо, що його жанрова генеза містить різні елементи. Перший з них, що привертає увагу, це виникаюча у другому такті інтонація зітхання (у верхньому голосі, т.2), яка спочатку охоплює інтервал терції, а потім розширюється до кварти i квінти. (Ця інтонація стане конструктивним елементом усієї п’єси і постійно зустрічається у мініатюри.) Подальше «розгойдування» даного елементу у висхідному і низхідному русі викликає асоціацію із жанром колискової. Це відчуття посилює остинато пульсуючих акордів у нижньому голосі (позначені штрихом legato i staccato), що завдяки своїй ритмічній організації (дві шістнадцятки і вісімка з акцентом на другій i четвертій вісімках) творять ефект заколисування.

Ще одним виразовим елементом у супроводі видається звук $f$ у верхньому голосі акордів, який повторюється впродовж 5 тактів і лише у 6 такті починає сповзати по звукам хроматичної гами. Аналогічну ідею постійного повернення одного і того ж звуку можна знайти в Прелюдіях (№ 4 e-moll, № 6 h-moll, op. 28) i Ноктюрнах (наприклад, № 3 g-moll, ор. 15) Ф. Шопена. Очевидно, що І. Я. Падеревський спирається на шопенівський принцип, але підпорядковує його реалізації власного задуму: у даному ноктюрні звук $f$ скоріше стає своєрідним фактурним і гармонічним стрижнем твору, ніж отримує образне і драматургічне навантаження, як у творах Ф. Шопена.

Повертаючись до початкового мелодичного мотиву хочеться звернути увагу на його неоднозначну ритмо-інтонаційну будову. На синтаксичному рівні цей елемент реалізований як ямбічний мотив, оскільки викладений синкопою (вісімка-чверть), що прагне до умовно сильної позиції такту. Але в інтерпретаційному аспекті він може розглядатись як хореїчний. Видається, що композитор намов би навмисне створює цю невизначеність, оскільки початковий звук даного інтонаційного елементу 3'являється в момент кульмінації іншої, прихованої в акордах мелодичної лінії $(f-f-b-a-a-g \mid c-g-\underline{e}) .3$ одного боку, можна трактувати короткий мотив у верхньому голосі i завершену мелодичну фразу приховану в акордах як дві окремі лінії, а 3 іншого - є очевидним, що вони знаходяться у тісній інтонаційній, ритмічній і фактурній взаємодії. 
Така діалогічність голосів не лише насичує музичну тканину мелодизмом, але й усі відхилення від метрики і уникнення акцентування сильних долей допомагають композитору створити відчуття легкості i об’ємність звукового простору.

\section{Приклад 1.}



Слід зазначити велике тематичне значення мелодичної лінії, яка створюється як нижній голос акордового шару $(f-b-a-g)$ і стає постійним контрапунктом до мелодичної лінії в крайніх розділах Ноктюрну. Також слід відзначити варіантність цього мотиву $(\boldsymbol{f}-b-a-g-\boldsymbol{d}-b-a-g)$, що обумовлюється особливим викладенням акордів і створює відчуття ладової перемінності ( $d-b-a-g$ в $B$-dur). Цей мотив в кожному такті чутко реагує на всі гармонічні зміни і на нюанси основної мелодичної лінії, створює неповторну насичену діалогічну фактуру крайніх розділів.

Наявність рис жанру колискової підтверджує розвиток даного мелодичного мотиву у відповідному ритмічному оформленні: т. 1 - b-ag, т. 2 - b-a-f, i далі у 5-6 тактах. Також, починаючи 3 т. 8 цей мотив поступово хроматизується (під впливом гармоніï), його інтонація набуває ліричного пафосу i приходить до локальної кульмінаційної вершини у т. 10 (d-des-c). Показово, що далі, в генеральній кульмінації першого розділу (тт. 20-21) цей мотив взагалі зникає, щоб всю увагу привернути до виразної мелодії у верхньому регістрі (ремарка con forza).

В обраних виконавських версіях описані особливості втілюються по-різному. Наприклад, Кевін Кіннер обирає спокійний темп, що 3 одного боку дозволяє піаністу створити ідеальний, на нашу думку, звуковий баланс між усіма елементами фактури, а 3 іншого - передати характерне для жанру ноктюрну (і колискової, окремі риси якої в ньому присутні) відчуття спокою. Американський виконавець майстерно об’єднує верхній голос і підголосок в єдиний мелодичний візерунок, що надає цілісності музичній фразі та виявляє створений І. Падеревським витончений діалог фактурних пластів. Для інтерпретації піаніста 
характерним $є$ інтимний тон вислову, він дотримується вказаної композитором динаміки і ремарок.

Натомість Хуберт Рутковскі пропонує жвавіший темп виконання, більшу диференціацію голосів і підсилення динамічних відтінків вказаних автором. За допомогою динаміки i значних агогічних відхилень піаніст виділяє мелодичну лінію верхнього голосу, як домінуючий елемент фактури і підпорядковує їй пульсацію акордів у супроводі. Так, Х. Рутковський дещо «згладжує» інтонаційне сплетіння різних голосів, він скоріше трактує цей діалог як колористичний ефект, як додаток до мелодичної лінії. Через постійні темпові відхилення у виконавській версії X. Рутковського жанрові ознаки колискової дещо губляться i за стилем виконання п’єса скоріше нагадує мендельсонівську пісню без слів.

Середній розділ вносить тематичний i образний контраст. Композитор переносить мелодичну лінію у віолончельний регістр, робить їі більш наспівною (ремарка molto cantando), а також полегшує акордову пульсацію (скорочує першу шістнадцятку i переносить супровід у верхній регістр). Однак ці незначні переміщення мелодії і супроводу не впливають на зміну настрою так, як виникнення нової ладо-тональності. І. Падеревський починає середній розділ 3 мінорної домінанти (f-moll) до основної тональності, що в мажорі завжди сприймається як різке гармонічне переключення. Можливо, саме тому початок середнього розділу видається дещо неочікуваним i «непідготовленим». Окрім цього, можна сказати, що в першому розділі превалювали низхідні мотиви, тоді як в середньому, навпаки, домінують висхідні інтонації.

Ще одним важливим, на нашу думку, моментом є кульмінація і закінчення даного розділу. Задля того, щоб органічно повернутися в репризі до музичного матеріалу першого розділу, І. Я. Падеревський використовує інтонацію зітхання i за допомогою ii секвенційного розвитку і прийому перегукування в різних регістрах, приводить до кульмінації. Цікаво, що з точки зору гармонії кульмінаційна вершина одночасно перетворюється у домінантовий передикт, звучання якого поступово розчиняється (ремарки diminuendo, rallentando molto, pianissimo) i органічно переходить до репризи (тт. 48-52). В цьому знову виявляються типово-романтичні риси щодо побудови музичного матеріалу: не зростання напруження за рахунок повторення домінанти (що характерно для домінантових предиктів у творах композиторівкласиків), а навпаки - поступове заспокоєння. 
Приклад 2.
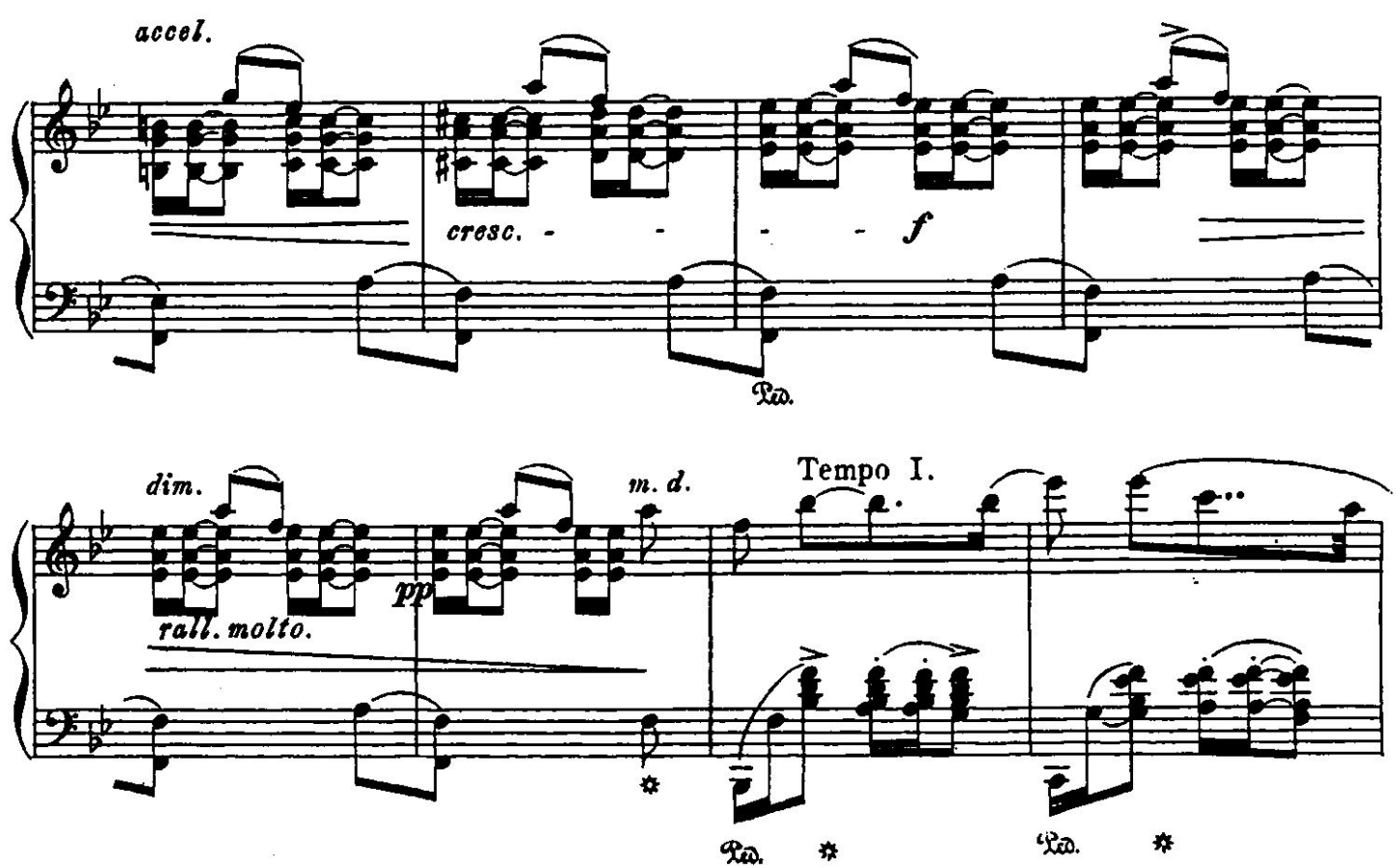

Х. Рутковський грає середній розділ пристрасніше, ніж К. Кіннер. Піаніст одразу обирає гучну динаміку, самостійно увиразнює верхній голос акордової вертикалі (у композиторському тексті немає жодних для того вказівок) і в окремих місцях повністю змінює авторські ремарки щодо динамічних відтінків і темпу виконання. Так, в момент виникнення ремарок forte $\mathrm{i}$ sforzando (тт. 41-42) Х. Рутковський зненацька приглушує звучання до ріano і уповільнює темп. Тоді як композиторські позначки rallentando molto піаніст практично ігнорує.

Тим часом у виконанні К. Кіннера середній розділ звучить набагато ліричніше. Американський виконавець підкреслює напруження гармонічного розвитку матеріалу, увиразнює найяскравіші моменти за допомогою гнучкого дихання i асинхронного взяття басу i акорду. Інакше К. Кіннер втілює домінантовий предикт до репризи. Піаніст чітко відтворює авторську динаміку, темпові позначення i в його виконанні повторення домінанти (протягом 5 тактів, ремарка rallentando molto) практично розчиняється у звуковому просторі.

У репризі І. Падеревський об'єднує усі ритмо-інтонаційні елементи, репрезентовані у першому розділі Ноктюрну, але загострює характер їх звучання. Композитор уникає пауз в мелодичній лінії (у верхньому голосі), робить ii менш переривчастою. Завдяки тому, що I. Падеревський переносить мелодію в на октаву вище, а бас у супроводі навпаки заглиблює, йому вдається створити відчуття ще більшого розширення звукового простору. 
Коду (останні 10 тактів) композитор будує на матеріалі перших двох тактів п’єси (інтонації зітхання і пульсації акордів), який поступово «розчиняється» у висхідному пасажі по звуках тоніки. Показовим є нове гармонічне забарвлення першого мотиву на початку коди, де він вперше отримує мажоро-мінорне звучання (т. $55, \mathrm{t}_{2}-\mathrm{VI}_{7}{ }^{\text {b }}$ ), що підсилює гармонічне навантаження коди.

Показовими видаються останні такти ноктюрну, які можна трактувати як своєрідне приношення Ф. Шопену. І. Падеревський пропонує типове для шопенівських творів хоральне завершення мініатюри, яке додається до витриманого довгими тривалостями звуку $f^{l}$. Таким чином вибудовується смислова арка до перших тактів ноктюрну, де даний звук створював окремий тематичний пласт.

\section{Приклад 3.}

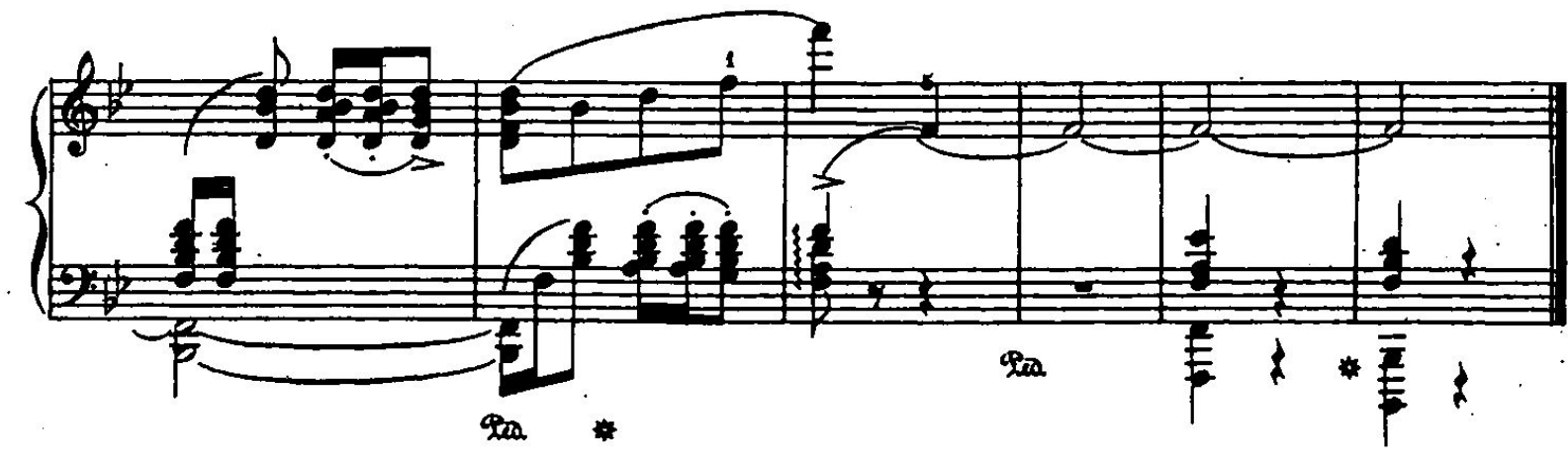

Підсумовуючи аналіз Ноктюрну I. Я. Падеревського слід зазначити, що композитор 3 одного боку демонструє відданість створеній Ф. Шопеном традицій, а з іншого - збагачує музичну мову власними пошуками. Щодо першого, то $\epsilon$ очевидним, що I. Падеревський наслідує шопенівський підхід до жанру: збагачує ноктюрн новими нюансами, зберігає чітку форму, усіма засобами підкреслює витонченість мелодизму і рафінованість музичної тканини. Щодо другого, то, на відміну від свого попередника І. Я. Падеревський ускладнює гармонічну мову за рахунок ладової перемінності і посилення колористичної функції гармонії. Композитор насичує акордову вертикаль мелодичними підголосками i, таким чином, створює багатошарову музичну фактуру. Ноктюрн I. Падеревського вбирає в себе провідні тенденції музичної мови к. XIX-п. XX ст.

Стильові особливості фортепіанної творчості І. Я. Падеревського яскраво виявляються у Ноктюрні № 4 та двох його виконавських інтерпретаціях, які демонструють варіантність нотного тексту композитора.

У версії Х. Рутковського відчувається дещо формальне ставлення музиканта до авторських вказівок. Піаніст не завжди дотримується 
динаміки, темпових позначень, а скоріше керується власними почуттями у виборі кульмінаційних моментів та ін. Видається, що в цьому можна вбачати «вільній» підхід виконавця до музичного тексту, який $\epsilon$ можливим в романтичній музиці, і який виражає суб'єктивну позицію інтерпретатора. Натомість треба зазначити, що Х. Рутковський відчуває та виразно втілює посилення колористичної функції гармонії у творі польського композитора, в чому виявляються сучасні для І. Я. Падеревського тенденції.

Кевін Кіннер грає Ноктюрн «по-шопенівські», 3 характерним інтимним і сповідальним ореолом. Американський піаніст увиразнює усі нюанси музичної тканини, чітко слідує за вказівками композитора i виявляє барвистість нотного тексту. Виконавець створює поетичну інтерпретацію, в якій одночасно проявляються розуміння піаністом авторської ідеї твору І. Я. Падеревського і прагнення виявити власний підхід до втілення усіх притаманних йому рис.

Так, кожен виконавець своєрідно трактує твір композитора, природно розширює рухомий потенціал нотного тексту, збагачує семантичне наповнення композиції, інтерпретує стильові особливості Ноктюрну І. Я. Падеревського і представляє своє «бачення» творчості польського митця.

1. Зильберман Ю. Омибка Гарольда Чарльза Шонберга. Об одной фотографии семьи Владимира Горовииа//Київське музикознавство: зб. $\mathrm{cm}$. HМАУ ім. П. I. Чайковського; КІМ ім. Р. М. Глієра. К., 2013. Вип. 47. С. 278-296.

2. Каньский Ю. Из истории польского исполнительства ХХ века. Советская музыка, 1997. №7. C. 111-114.

3. Москаленко В. Лекиии по музыкальной интерпретащии: учебное пособие. К., 2013. 272 c.

4. Сітенко Т. Київські епізоди творчої біографії I. Падеревського//Науковий вісник (історія музики: нові факти та інтерпретаціï). К., 2004. №42. C. 40-51.

5. Actes des conférences. A. Cortot musicien du XX siècle, perspectives biographiques. Journées internationales Alfred Cortot. Actes des conférences 4-8 juillet 2012.

6. Bajerska A. Obraz Paryża w literaturze pozytywizmu i Młodej Polski (Praca doktorska), Uniwersytet Łódzki Studium Doktoranckie Języka, Literatury $i$ Kultury Wydziatu Filologicznego. Łódź, 2017. 277 str.

7. Compagnon A. Anna de Noailles. URL: // https://www.universalis.fr/encyclopedie/annade-noailles/ (дата звернення: 15.04.2018).

8. Gazette artistique de Nantes: journal artistique et littéraire, paraissant une fois par semaine. 16/10/1890.

9. Paprocka P., Mierzejewska M. Ignacy Jan Paderewski - kompozytor i pianista. URL: http://skorzewo.edu.pl/szkola/patron/patron.php (дата звернення: 15.04.2018).

10. Wapiński Roman. Ignacy Paderewski, Zakład Narodowy im. Ossolińskich Wydawnictwo, Wrocław, 1999. 


\section{References}

1. Zilberman, Yu. (2013). Mistake of Garold C. Schonberg. About one photo of the Horowitz's family [Oshy'bka Garol'da Charl'za Shonberga. Ob odnoj fotografiyi sem'yi Vladimira Gorovica]. Musicology of Kyiv: a collection of articles, NMAU named by P. I. Tchaikovsky; R. Glier Kyiv Institute of music, issue 47. p. 278-296 [in Russian].

2. Kansky, Yu. (1997). From the history of Polish performance of the XX century [Iz istorii pol'skogo ispolnitel'stva XX veka]. Soviet music, №7. p. 111-114 [in Russian].

3. Moskalenko, V. (2013). Lectures on musical interpretation: a tutorial [Lekcii po muzykal'noj interprepaciyi: uchebnoje posobije]. Kyiv, 272 p. [in Russian].

4. Sitenko, T. (2004). Kyiv episodes of I. J. Paderevsky's creative biography. Scientific herald (music history: new facts and interpretations) [Ky'yivs'ki epizody tvorchoyi biografiyi I. Paderevs'kogo. Naukovy'j visny'k (istoriya muzy'ky: novi fakty ta interpretaciyi)]. Kyiv, №42. p. 40-51 [in Ukrainian].

5. Actes des conférences. A. Cortot musicien du XX siècle, perspectives biographiques. Journées internationales Alfred Cortot. Actes des conférences 4-8 juillet 2012 [in French].

6. Bajerska, A. (2017). Obraz Paryża w literaturze pozytywizmu i Młodej Polski (Praca doktorska), Uniwersytet Łódzki Studium Doktoranckie Języka, Literatury i Kultury Wydziału Filologicznego. Łódź: 277 str. [in Polish].

7. Compagnon, A. Anna de Noailles. Encyclopaedia Universalis [online]. Available at: https://www.universalis.fr/encyclopedie/anna-de-noailles/ [Accessed 15 april 2018] [in French].

8. Gazette artistique de Nantes. Journal artistique et littéraire. 16 octobre 1890 [in French].

9. Paprocka, P., Mierzejewska, M. Ignacy Jan Paderewski-kompozytor i pianista. [online]. Available at: http://skorzewo.edu.pl/szkola/patron/patron.php [Accessed 15 april 2018] [in Polish].

10. Wapiński, R. (1999). Ignacy Paderewski. Wrocław: Zakład Narodowy im. Ossolińskich, 235 s. [in Polish]. 